\title{
コンピュータによる二重組織織物のシミュレーション
}

\begin{tabular}{|c|c|c|c|c|}
\hline 京都工芸織維大学研究生 & 王 & & 躍 & 存 ${ }^{*}$ \\
\hline 京都工芸繊維大学繊維学部 & 中 & 島 & & 勝（会員） \\
\hline 京都工芸繊維大学繊維学部 & & 倉 & 弘 & 樹（会員） \\
\hline 京都工芸繊維大学繊維学部 & & 瀬 & & \\
\hline
\end{tabular}

\section{Graphic Simulation of Double Cloth by Computer}

Yuecun Wang, Masaru Nakajima, Hiroki Ishikura and Susumu Kase

Kyoto Institute of Technology, Sakyo-ku, Kyoto

\section{1. 緒 言}

最終的に商品として生産される織物は, 多数の試 作品の中から選択される. 試作品の製作期間を短縮 することと，そのコストを低減するために，多くの 織物用デザインシミュレーションシステムが開発さ れ, 織物の柄のシミュレーションが行われている. しかし現在のところ, その大部分は, 一般的な織物 組織について開発されており, 二重組織に用いるこ とのできるデザインシミュレーションシステムは見 られない. また研究報告としては, A. Newton ら ${ }^{1.2)}$ が, 最表面を覆う糸が明らかな場合について, 多重 織物の幾何学的な構造や色糸効果についてシミュレ ーションを行っているが, 二重組織では最表面を覆 う糸の特定が困難な場合がある，そこで本報では重 ね判定数を用いた二重織物のシミュレーションシス テムを開発したので,この結果を報告する.

\section{2. 隣接する糸との重なり}

一般的な組織の織物では, 隣接する糸同士の重な りは起こらない，つまり図 1 に示すように, 糸同士 の重なりは各交差点でたて糸がよこ糸に対して浮く か, よこ糸がたて糸に対して浮くかの 2 種類の内ど ちらかである。

重ね組織ではたて糸かよこ糸のいずれか，または
両方を 2 種類以上用いるため, 織物中で隣接するた て糸間あるいはよこ糸間で重なりが生じる.片二重 織物（たて二重またはよこ二重）は 3 本の糸が重な り, $3 !=6$ の重ね状態が生じ, 二重組織（たて・よこ とあに二重) では 4 本の糸が重なり $4 !=24$ の重ね状 態が生じる. 図 2 にたて二重織の重なりの状態を示 す.
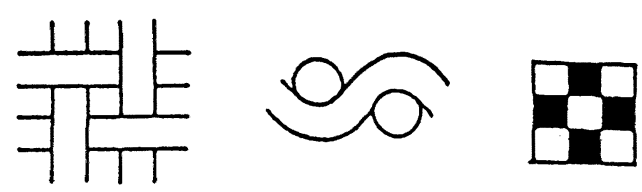

図 1 平織組織
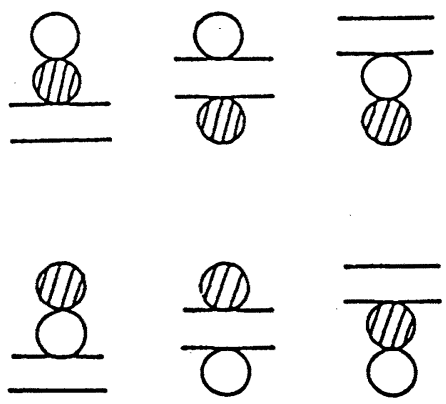

図 2 たて二重組織 


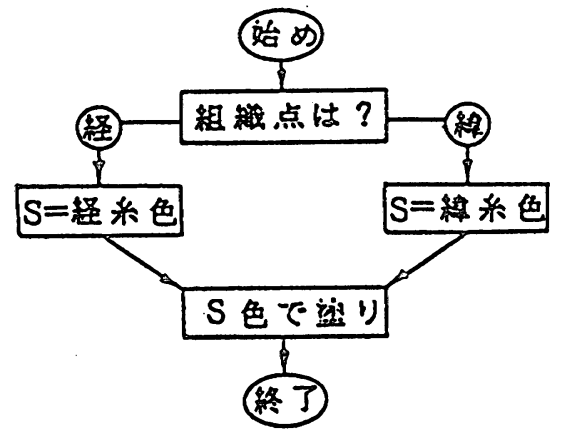

図 3 一般の織物の色糸効果

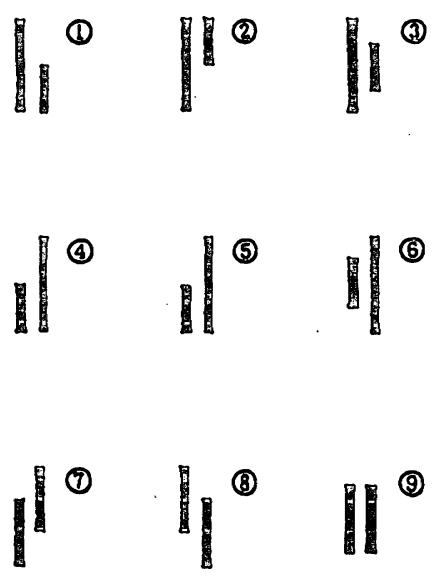

図 4 隣接する浮き糸の長さの組み合わせ

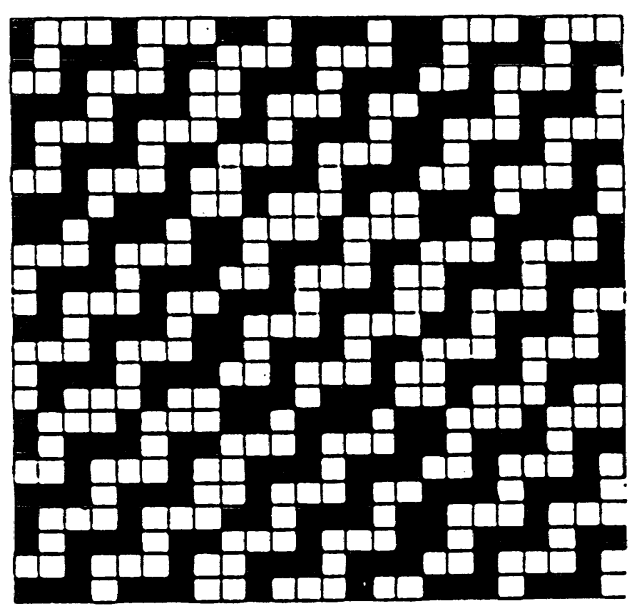

困 5 重ね組織の組織図
色糸効果は最表面を覆う糸の色によって決まるた め, 一般的な組織の織物では, その重なり状態では, 組織図中のたて糸とよこ糸の組織点に対応する。こ のため図 3 に示すように表面系の判定は簡単にでき る。しかし重ね組織では，隣接する糸同士の重なり があるため, 最表面を覆う系の判定は, 組織点だけ からでは行うことができない，例えば図 2 の左端に 示す 2 種類の組織の場合， 2 本のたて糸はすべてよ こ系に対して浮いているが，たて糸間の上下関係 は，この図からだけでは判断することができない，

\section{3. 浮き糸の判定}

織物表面の柄は，色と長さが異なるたて方向とよ こ方向の浮き系の分布によって決定される。つまり 浮き系は, 柄の基本単位と考えられるが, 浮き系の 分布は当然組織によって決定される. 浮き系の長さ を, 浮き系が越えた直交する糸の本数で定義する と, 平織りの浮き系の長さは 1 になり， $2 / 2$ 斜紋織 りの浮き糸の長さは 2 になる. 重的組織中の隣接す る浮き系の分布は図 4 のように模式図的に表せる. 状態(1)〜6では，隣接する浮き系間に重なりが生じ るが, (1)〜(3)では左側の浮き糸が右側の浮き糸を覆 い, (4)〜6では右側の浮き糸が左側の浮き系を覆 う. (7)，8)では浮き糸同士の重なりは生じず，9で は重なりが生ずるか否かは他の条件によって決ま る. 例えば図 5 に示すように, 重的組織の組織図は 複雑な場合が多く，隣接する浮き系間の重なりの状 態を判定することは容易ではない．筆者らは以下の 方法で, 浮き系の重なり状態を判定できると考え る.

浮き糸同士が重なるか否かは, 主に浮き系の両端 の状態によって決められるので, 両端の状態により 重ね指数を求め,この重ね指数を浮き系が重なるか 否汃の判定基準に用いる. 図6を例として考え，ま ず浮き糸 $A B$ の右端について分析する．表浮き系 $A B$ の長さを $L_{0}$, 裏浮き系 $B C$ の長さを $L_{1}$ とし, $B$ を原点とする. 次に隣接する浮き糸の中で, 系の右 端が原点より正の方向にありかつ最む原点に近い位 置の糸の左端 $D$ の位置を $X$ とする。この場合重ね 指数 $\lambda_{0}$ を

$$
\lambda_{0}= \begin{cases}X / L_{0} & \left(-L_{0} \leqq X \leqq 0\right) \\ X / L_{1} & \left(0<X \leqq L_{1}\right.\end{cases}
$$

とする.

ここでは, $X \leqq-L_{0}$ の場合 $X=-L_{0}$ として $X \geqq$ $L_{1}$ の場合 $X=L_{1}$ とする。 つまり $\lambda_{0}$ は -1 から 1 の 


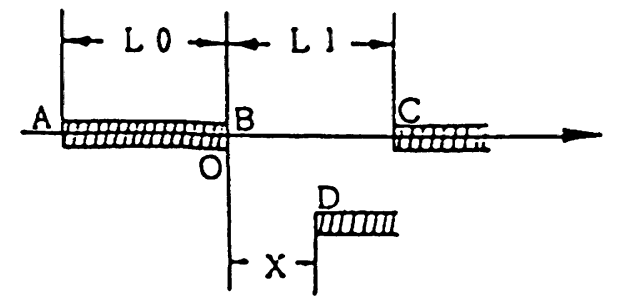

図6 重ね枚数のモデル

間の值をとる.この値は浮き糸の右端が隣接する浮 き系を覆う可能性の大きさを示している，同様の方 法で左端の重ね指数 $\lambda_{1}$ を求める. 浮き糸の重ね指 数は両端の平均值で表せると考え, $\lambda$ で表すと, 浮 き糸 $A B$ の重ね指数は(2)式となる.

$$
\lambda=\left(\lambda_{0}+\lambda_{1}\right) / 2
$$

与えられた織物の重ね判定数 $\alpha$ と $\beta$ に対して, $\lambda$

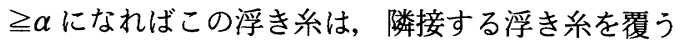

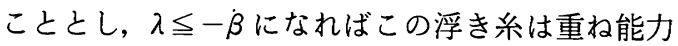
がなく, 隣接するよこ系を覆うことも覆われること あないとする. この 3 種類の状態を $k$ で表すと

$$
k=\left\{\begin{aligned}
1 & (\lambda \geqq \alpha) \\
0 & (-\beta<\lambda<\alpha) \\
-1 & (\lambda \leqq-\beta)
\end{aligned}\right.
$$

この $k$ を用いた色糸効果のシミュレーションは 図 7 のように考えられる.

以上は片二重組織の色糸効果の判定方法である が，二重組織に対しては，

\section{4. 実例および考察}

前述のシミュレーション方法で 3 種類の重ね組織 の柄を作成したので，その組織図と色糸効果を図 8 〜10に示す.ここでは, $\alpha, \beta=0.5$ としてシミュレー ションを行っている. 図 8 は平織り二重組織の柄で ある. 図 9 は 2 色のたて糸と 2 色のよこ糸を 1 対 1 に配列した 4 色の二重織物である。図10は斜紋組織 と二重組織を組み合わせた組織である.

織物の浮き糸を, 色糸効果の分析の基本単位とし て, 各浮き系の重ね指数を求め, 重ね判定を行い, 色糸効果のシミュレーションを行った.この方法 は，複雑な組織について対応することができれば, その実用性は高いと考える.今後は実際の試織とそ

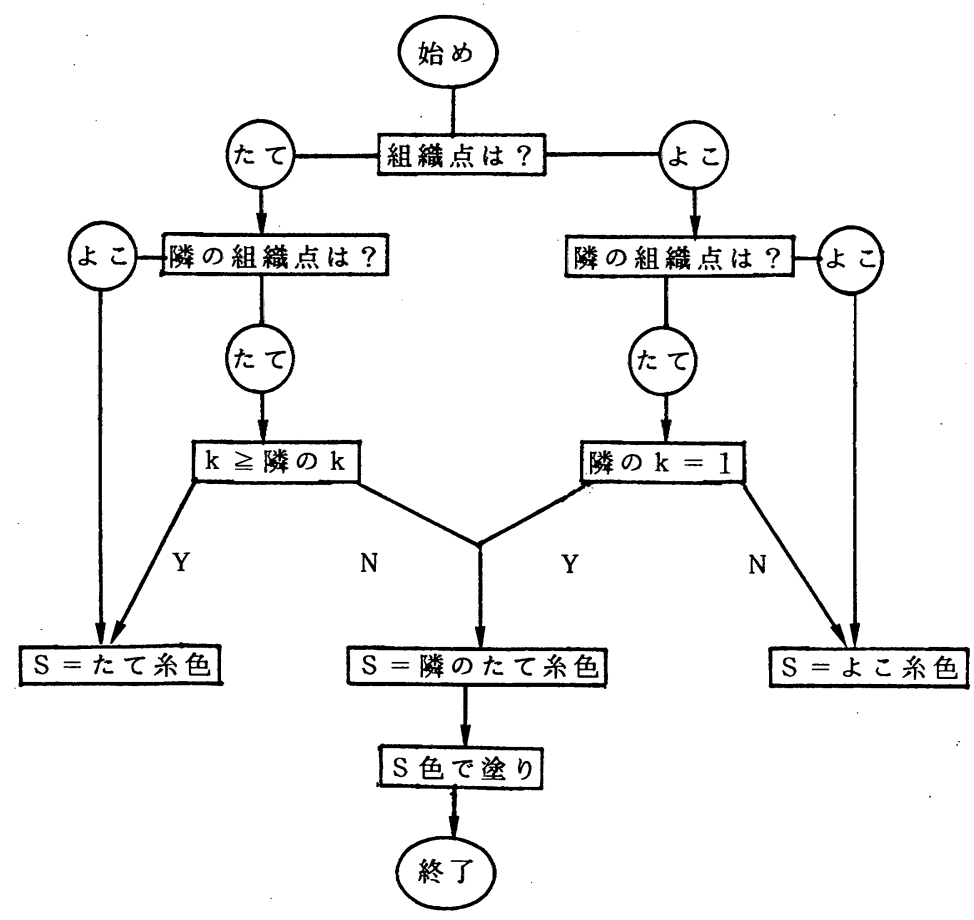

図 7 たて糸二重の色糸効果 

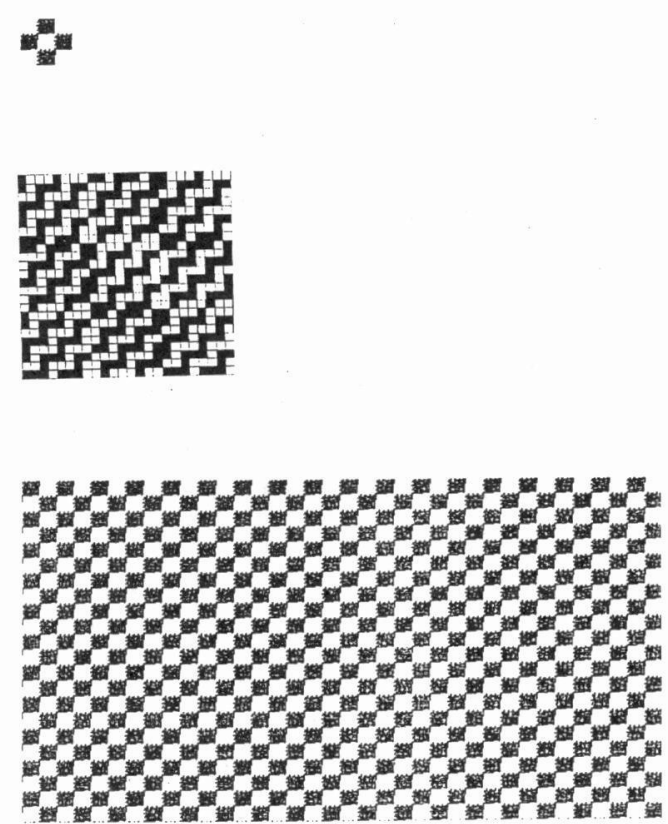

図 8 シミュレーション例
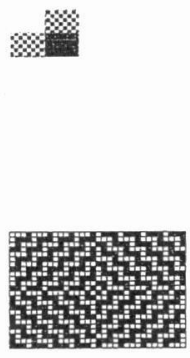

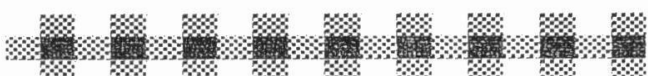
\%

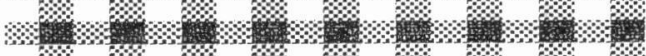
\% 1 r.

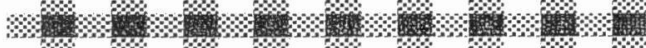
\%

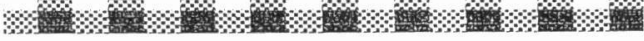

図 9 シミュレーション例
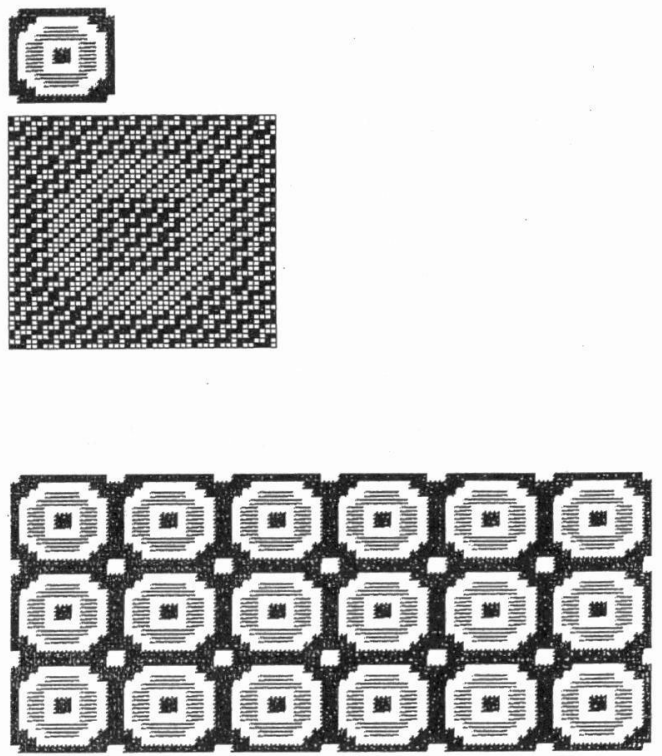

四10 シミュレーション例

の織物に対応した重敉判定数 $\alpha, \beta$ の検討が必要と 考える。

\section{5. 結 言}

重ね組織の浮き系を基本単位として, 浮き糸の重 対能力を算出し, 重ね判定数により, 最表面を覆う 浮き系を決定する方法を検討した。この方法は, 複 雑な重斌組織に適応できることが分かったので，今 後実験により，その実用性を確認する必要があると 考える.

\section{謝辞}

本報告の図面は本学研究生の馮丹宇君（浙江綵綢 工学院）の作成によるものである．同君に謝意を表 す.

\section{参考文献}

1) A. Newton and B. P. Sarkar ; J. Text. Inst., 70, 427 (1979)

2) Gu. Ping and A. Newton; J. Text. Inst., 78, 54 (1987)

(Received October 30, 1992) (Accepted for Publication February 9, 1993) (平成 4 年10月30日受理)

(平成 5 年 2 月 9 日審査終了) 